\title{
Antioxidant and Antiradical Properties of Selected Flavonoids and Phenolic Compounds
}

\author{
Zübeyir Huyut, ${ }^{1}$ Şükrüi Beydemir, ${ }^{2}$ and İlhami Gülçin ${ }^{3}$ \\ ${ }^{1}$ Department of Biochemistry, Medical Faculty, Yuzuncu Yıl University, 65080 Van, Turkey \\ ${ }^{2}$ Department of Biochemistry, Faculty of Pharmacy, Anadolu University, 26210 Eskişehir, Turkey \\ ${ }^{3}$ Department of Chemistry, Faculty of Sciences, Atatürk University, 25240 Erzurum, Turkey
}

Correspondence should be addressed to Zübeyir Huyut; zubeyir.huyut@gmail.com

Received 13 June 2017; Accepted 7 September 2017; Published 12 October 2017

Academic Editor: Paul W. Doetsch

Copyright (C) 2017 Zübeyir Huyut et al. This is an open access article distributed under the Creative Commons Attribution License, which permits unrestricted use, distribution, and reproduction in any medium, provided the original work is properly cited.

\begin{abstract}
Phenolic compounds and flavonoids are known by their antioxidant properties and one of the most important sources for humans is the diet. Due to the harmful effects of synthetic antioxidants such as BHA and BHT, natural novel antioxidants have become the focus of attention for protecting foods and beverages and reducing oxidative stress in vivo. In the current study, we investigated the total antioxidant, metal chelating, $\mathrm{Fe}^{3+}$ and $\mathrm{Cu}^{2+}$ reduction, and free radical scavenging activities of some phenolic and flavonoid compounds including malvin, oenin, ID-8, silychristin, callistephin, pelargonin, 3,4-dihydroxy-5-methoxybenzoic acid, 2,4,6-trihydroxybenzaldehyde, and arachidonoyl dopamine. The antioxidant properties of these compounds at different concentrations $(10-30 \mu \mathrm{g} / \mathrm{mL})$ were compared with those of reference antioxidants such as BHA, BHT, $\alpha$-tocopherol, and trolox. Each substance showed dose-dependent antioxidant activity. Furthermore, oenin, malvin, arachidonoyl dopamine, callistephin, silychristin, and 3,4-dihydroxy-5-methoxybenzoic acid exhibited more effective antioxidant activity than that observed for the reference antioxidants. These results suggest that these novel compounds may function to protect foods and medicines and to reduce oxidative stress in vivo.
\end{abstract}

\section{Introduction}

Reactive oxygen species (ROS) are continuously formed by normal cellular processes endogenously and environmental factors exogenously [1]. ROS include nonradical species such as hydrogen peroxide $\left(\mathrm{H}_{2} \mathrm{O}_{2}\right)$, hypochlorous acid $(\mathrm{HOCl})$, singlet oxygen $\left({ }^{1} \mathrm{O}\right)$, and free radicals such as superoxide anion radical $\left(\mathrm{O}_{2}{ }^{--}\right)$, hydroxyl radical $\left(\mathrm{OH}^{\bullet}\right)$, and hydroperoxide $\left(\mathrm{ROO}^{\circ}\right)$ [2-4]. Free radicals at physiological concentrations have a series of useful biological functions such as acting as a cell signaling molecule; functioning against cellular responses; controlling cell viability, migration, and differentiation; protecting cells against pathological and infectious agents and inactivating them [5-7]. However, levels of ROS higher than physiological concentrations cause oxidative-antioxidant imbalance and oxidative stress [8]. Oxidative stress is a factor that induces a number of diseases such as atherosclerosis, cardiovascular diseases, diabetes, inflammation, aging, skin lesions, rheumatoid arthritis, and neurological diseases [9-11]. When enzymatic or nonenzymatic endogenous antioxidants are inadequate to remove ROS from the body, it becomes important for the body to receive exogenous natural antioxidants such as phenolic compounds.

Phenolic compounds are secondary plant metabolites that are found naturally in all plant materials, including plantbased food products [12]. These compounds are thought to be an integral part of human and animal diets. They represent the most important group of natural antioxidants [13]. The most common phenolic compounds in plants can be classified into phenolic acids, tocopherols, and flavonoids [14]. It has been reported that phenolic and flavonoid compounds act as antioxidants to exert antiallergic, antiinflammatory, antidiabetic, antimicrobial, antipathogenic, antiviral, antithrombotic, and vasodilatory effects and prevent diseases such as cancer, heart problems, cataracts, eye disorders, and Alzheimer's [15-17]. In addition, the most important features of flavonoids include their ability to 
protect against oxidative diseases, activate or inhibit various enzymes bind specific receptors, and protect against cardiovascular diseases by reducing the oxidation of low-density lipoproteins [18].

Various methods have been developed to investigate the antioxidant properties of a substance. These include assays for total antioxidant capacity (TAC), $\mathrm{NO}^{\bullet}, \mathrm{H}_{2} \mathrm{O}_{2}, \mathrm{O}_{2}{ }^{--}$, and $\mathrm{OH}^{\bullet}$ radical scavenging capacity; oxygen radical scavenging activity (ORAC); $\mathrm{Fe}^{3+}$ and $\mathrm{Cu}^{2+}$ reducing activity (FRAP and CUPRAC assay, resp.); metal chelating activity; $\mathrm{ABTS}^{\bullet+}$, $\mathrm{DMPD}^{\bullet+}$, and $\mathrm{DPPH}^{\bullet}$ free radical scavenging activity; and lipid peroxidation inhibition capacity [19-21]. Among these, the most commonly used methods are TAC determination and assays for determining $\mathrm{Fe}^{+3}$ and $\mathrm{Cu}^{+2}$ reduction activity, metal chelating ability, and free radical $\left(\mathrm{ABTS}^{\circ+}, \mathrm{DPPH}^{\bullet}\right.$, $\mathrm{DMPD}^{\bullet+}, \mathrm{OH}^{\bullet}$, and $\mathrm{O}_{2}{ }^{--}$) scavenging activity [21].

In the current study, we investigated the antioxidant capacities of malvin, oenin, ID-8, silychristin, callistephin, and pelargonin with flavonoid structures and 3,4-dihydroxy5-methoxybenzoic acid, arachidonoyl dopamine, and 2,4,6trihydroxybenzaldehyde with phenolic structures (Figure 1) by assaying, $\mathrm{Fe}^{3+}$ and $\mathrm{Cu}^{2+}$ reduction activity, metal chelating activity, and $\mathrm{O}_{2}{ }^{--}, \mathrm{ABTS}^{\bullet+}, \mathrm{DPPH}^{\bullet}$, and $\mathrm{DMPD}^{\circ+}$ radical scavenging capacity.

\section{Materials and Methods}

2.1. Chemicals. Sodium dihydrogen phosphate $\left(\mathrm{NaH}_{2} \mathrm{PO}_{4}\right)$, potassium ferrocyanide $\left(\mathrm{K}_{3} \mathrm{Fe}(\mathrm{CN})_{6}\right)$, trichloroacetic acid (TCA), iron-III-chloride $\left(\mathrm{FeCl}_{3}\right)$, potassium peroxydisulfate $\left(\mathrm{K}_{2} \mathrm{O}_{8} \mathrm{~S}_{2}\right)$ copper-II-chloride $\left(\mathrm{CuCl}_{2}\right)$, sodium acetate $\left(\mathrm{NaCH}_{3} \mathrm{COO}\right)$, hydrochloric acid $(\mathrm{HCl})$, tris, iron-II-sulfate $\left(\mathrm{FeSO}_{4}\right)$, iron-II-chloride $\left(\mathrm{FeCl}_{2}\right)$, disodium hydrogen phosphate $\left(\mathrm{Na}_{2} \mathrm{HPO}_{4}\right)$, methionine, ethanol, ethylenediaminetetraacetic acid (EDTA), ammonium thiocyanate $\left(\mathrm{NH}_{4} \mathrm{SCN}\right)$, sodium bicarbonate $\left(\mathrm{NaHCO}_{3}\right)$, sodium hydroxide $(\mathrm{NaOH})$, disodium sulfate $\left(\mathrm{Na}_{2} \mathrm{SO}_{4}\right)$, sodium perchlorate $\left(\mathrm{NaClO}_{4}\right)$, and disodium carbonate $\left(\mathrm{Na}_{2} \mathrm{CO}_{3}\right)$ were obtained from Merck (Merck, made in Germany). Cis-9, cis-12-octadecanoic acid (linoleic acid), 2,2-diphenyl-1-picrylhydrazyl (DPPH), polyoxyethylene sorbitan monolaurate (Tween 20), nitroblue tetrazolium (NBT), 3-(2-pyridyl)-5,6diphenyl-1,2,4-triazine- $4^{\prime}, 4^{\prime \prime}$-disulfonic acid sodium salt (ferrozine), riboflavin (vitamin B2), N-N-Dimethyl-p-phenyl-enediamine dihydrochloride (DMPD), neocuproine hydrate $\left(\mathrm{C}_{4} \mathrm{H}_{12} \mathrm{~N}_{2} \cdot X \mathrm{H}_{2} \mathrm{O}\right), 2,2^{\prime}$-azino-bis(3-ethylbenzothiazoline-6-sulfonic acid) diammonium sulfate (ABTS), ID$8 \quad\left(\mathrm{C}_{6} \mathrm{H}_{14} \mathrm{~N}_{2} \mathrm{O}_{4}\right)$, 3,4-dihydroxy-5-methoxybenzoic acid $\left(\mathrm{C}_{8} \mathrm{H}_{8} \mathrm{O}_{5}\right)$, silychristin $\left(\mathrm{C}_{25} \mathrm{H}_{22} \mathrm{O}_{10}\right)$, malvin $\left(\mathrm{C}_{29} \mathrm{H}_{28} \mathrm{O}_{17}\right)$, pelargonin $\left(\mathrm{C}_{27} \mathrm{H}_{31} \mathrm{O}_{15}\right)$, oenin $\left(\mathrm{C}_{23} \mathrm{H}_{25} \mathrm{O}_{2}\right)$, arachidonoyl dopamine $\left(\mathrm{C}_{28} \mathrm{H}_{41} \mathrm{NO}_{3}\right)$, callistephin $\left(\mathrm{C}_{21} \mathrm{H}_{21} \mathrm{O}_{10}\right)$, and 2,4,6-trihydroxy-benzaldehyde $\left(\mathrm{C}_{6} \mathrm{H}_{2} \mathrm{CHO}\right)$ were purchased from Sigma Aldrich Company (St Louis, MO, USA).

2.2. Determination of TAC. TAC was determined by the thiocyanate method [22]. Different concentrations of the stock solutions $(10,20,30 \mu \mathrm{g} / \mathrm{mL})$ of phenolic and flavonoid compounds were added to tubes and volume was brought to $2.5 \mathrm{~mL}$ using phosphate buffer $(0.01 \mathrm{M}$ and $\mathrm{pH} 7.4)$.
Subsequently, $2.5 \mathrm{~mL}$ of linoleic acid emulsion was added to each tube, and the mixture was incubated at $37^{\circ} \mathrm{C}$ in the dark. Samples $(100 \mu \mathrm{L})$ were taken every $12 \mathrm{~h}$ during incubation, to which $4.7 \mathrm{~mL}$ of ethanol, $100 \mu \mathrm{L}$ of $\mathrm{SCN}^{-}$solution, and $100 \mu \mathrm{L}$ of $\mathrm{Fe}^{2+}$ solution $(20 \mathrm{mM})$ prepared in $\mathrm{HCl}(3.5 \%)$ were added. The absorbance of the samples at $500 \mathrm{~nm}$ was measured and compared to that of blank solution. Alcohol was used instead of the sample for the blank, while buffer solution was used instead of the sample for the control. The incubation and absorbance measurements were continued until the maximum absorbance values of the control sample were reached (about $1.5 \mathrm{~d}$ ).

2.3. Determination of $\mathrm{Fe}^{3+}-\mathrm{Fe}^{2+}$ Reduction Activity by FRAP Reagent (FRAP Assay). The reduction power as FRAP reactivity was determined using the method of Oyaizu with slight modification [23]. Different solutions $(10,20,30 \mu \mathrm{g} / \mathrm{mL})$ were prepared from the $1 \mathrm{mg} / \mathrm{mL}$ stock solutions of the phenolic and flavonoid compounds. The sample volume in the tubes was to $0.5 \mathrm{~mL}$ using acetate buffer ( $\mathrm{pH}$ 3.6). Subsequently, $2.25 \mathrm{~mL}$ of $\mathrm{FeCl}_{3}$ solution and $2.25 \mathrm{~mL}$ of FRAP reagent were added to each tube (total volume $5 \mathrm{~mL}$ ). After incubation for $10 \mathrm{~min}$, the absorbance of the mixture was read at $593 \mathrm{~nm}$ against the blank. Acetate buffer was used as a blank control sample.

2.4. $\mathrm{Cu}^{2+}-\mathrm{Cu}^{+}$Reduction Activity (CUPRAC Assay). The $\mathrm{Cu}^{2+}$ reduction activity was determined using the method previously described by Apak et al. with a minor modification [24]. Different concentrations $(10,20$, and $30 \mu \mathrm{g} / \mathrm{mL})$ of phenolic and flavonoid compounds were mixed with $125 \mu \mathrm{L}$ of $\mathrm{CuCl}_{2}$ solution $(0.01 \mathrm{M}), 125 \mu \mathrm{L}$ of ethanolic neocuprin solution $(7.5 \mathrm{mM})$, and $125 \mu \mathrm{L}$ of ammonium acetate buffer solution (1M). After incubation in the dark for $30 \mathrm{~min}$, absorbance was measured at $450 \mathrm{~nm}$ against a distilled water blank.

2.5. Superoxide Anion Radical $\left(\mathrm{O}_{2}{ }^{--}\right)$Scavenging Activity. Superoxide anion radical scavenging activity was determined using the method described by Zhishen et al. with slight modification [25]. This method is based on the spectrophotometric measurement of nitroblue tetrazolium (NBT). Different concentrations of samples and standards were prepared in phosphate buffer $(0.05 \mathrm{M}$ and $\mathrm{pH} 7.8)$. To the sample solutions, riboflavin, methionine, and NBT were added at concentrations of $13.3,44.6$, and $81.5 \times 10^{-2} \mu \mathrm{M}$, respectively. The reaction mixture was stimulated with $20 \mathrm{~W}$ of fluorescent light at room temperature for $2 \mathrm{~h}$. Absorbance was measured at $560 \mathrm{~nm}$ against a distilled water blank.

2.6. DPPH Radical Scavenging Activity. The DPPH radical scavenging activity was analyzed according to the method of Blois [26]. DPPH solution (1 mM) was used as the free radical. The previously prepared $1 \mathrm{mg} / \mathrm{mL}$ antioxidant stock solutions were used. Samples were added to test tubes at concentrations of 10,20 , and $30 \mu \mathrm{g} / \mathrm{mL}$ and the total volume was brought to $2.5 \mathrm{~mL}$ using pure ethanol. Subsequently, $0.5 \mathrm{~mL}$ of the stock DPPH solution was added to each sample tube. After 
<smiles></smiles>

Oenin<smiles></smiles>

Pelargonin<smiles>COc1ccc(-n2c(C)c([N+](=O)[O-])c3ccc(O)cc32)cc1</smiles>

ID-8<smiles>CCCCC/C=C\C/C=C\C/C=C\C/C=C\CCCC(=O)NCCc1ccc(O)c(O)c1</smiles>

Arachidonoyl Dopamine<smiles></smiles>

Callistephin

Silychristin<smiles>COc1cc(C(=O)O)cc(O)c1O</smiles>

3,4-Dihydroxy-5methoxybenzoic acid<smiles>COc1cccc(O)c1O</smiles>

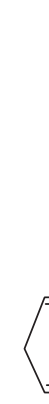


transferred to the test tubes and the total volume was brought to $0.5 \mathrm{~mL}$ using distilled water. One milliliter of DMPD ${ }^{\bullet+}$ solution was added to the solution and absorbance values were measured at $505 \mathrm{~nm}$ after incubation for $50 \mathrm{~min}$. Buffer solution was used as a blank [28].

2.9. $\mathrm{Fe}^{2+}$ Chelating Activity. Metal chelating activities of the phenolic and flavonoid compounds and positive control substances were assay using the method previously described by Dinis et al. [29]. The phenolic and flavonoid compounds were added at different concentrations $(10,20$, and $30 \mu \mathrm{g} / \mathrm{mL})$ to a solution containing $50 \mu \mathrm{L}$ of $\mathrm{FeCl}_{2} \cdot 4 \mathrm{H}_{2} \mathrm{O}(2 \mathrm{M})$ and $350 \mu \mathrm{L}$ of purified water. The final volume was brought to $4 \mathrm{~mL}$ using distilled water. The reaction was initiated by adding $0.2 \mathrm{~mL}$ of ferrozine solution ( $5 \mathrm{mM}$ ). After the solution was thoroughly mixed by vortexing, it was incubated at room temperature for $10 \mathrm{~min}$. Subsequently, the absorbance values were measured at $562 \mathrm{~nm}$ against an ethanol blank. As a control, a solution lacking any phenolic or flavonoid compounds was used.

\section{Results and Discussion}

Antioxidant compounds exert their effects through different mechanisms such as inhibiting hydrogen abstraction, binding transition metal ions, radical scavenging, and disintegrating peroxides $[30,31]$. One of the most important factors influencing antioxidant capacity is the ability of the antioxidant to donate electrons. Due to the harmful effects of synthetic antioxidants such as BHA and BHT, antioxidant capacities of flavonoids and phenolic compounds in plant-derived or natural origin have garnered substantial research interest and are being investigated extensively [32]. Many methods have been developed to determine the antioxidant capacities of synthetic or naturally sourced compounds, plant extracts, and other samples. Among these methods, TAC; reducing power, $\mathrm{DPPH}, \mathrm{DMPD}, \mathrm{ABTS}^{\bullet+}$, and $\mathrm{O}_{2}{ }^{--}$scavenging ability; and metal chelating activities are the most frequently used [21].

TAC determination is a method that encompasses many factors, which are captured individually by other methods. Since TAC is affected by metal chelating capacity, reducing power, and free radical scavenging activity of compounds (e.g., by the number of - $\mathrm{OH}$ groups bound to aromatic rings and conjugate diene structure of antioxidant molecules), it is obvious that each method should be applied and evaluated separately [33].

TAC determination is widely used for clinically used bioactive substances and compounds that are food ingredients. TAC can also be defined as the capacity to inhibit lipid peroxidation of compounds [34]. The ability to inhibit linoleic acid emulsion is tested to determine possible total antioxidant effects of a bioactive compound [35]. Linoleic acid emulsion ultimately produces hydroperoxides and the resulting hydroperoxides decompose to form secondary products. In this method, the amount of hydroperoxide from the linoleic acid resulting from autoxidation is measured indirectly during the test period. Hydroperoxides react with $\mathrm{Fe}^{2+}$ to form $\mathrm{Fe}^{3+}$. These secondary ions $\left(\mathrm{Fe}^{3+}\right)$ form complexes with thiocyanate $\left(\mathrm{SCN}^{-}\right)$. The resulting $\mathrm{Fe}(\mathrm{CN})^{2+}$ complex exhibits a maximum absorbance at $500 \mathrm{~nm}$. The oxidation of linoleic acid is slow in the presence of antioxidants [36]. Therefore, the greater the ability to inhibit the oxidation of $\mathrm{Fe}^{2+}$ to $\mathrm{Fe}^{3+}$ of the antioxidant substance, the lower the absorbance will be. In this study, the thiocyanate method was used to determine the TAC of a reference antioxidant and various phenolic and flavonoid compounds: their ability to inhibit linoleic acid emulsion at a $20 \mu \mathrm{g} / \mathrm{mL}$ concentration was determined. ID-8, callistephin, malvin, and oenin had higher inhibitory effects than all reference antioxidants used, with $97.98 \%$, 98.90\%, 96.75\%, and 96.7\% inhibition values, respectively, at 36 th $\mathrm{h}$ (Table 1 ).

In addition, malvin, pelargonin, and silychristin exhibited inhibition values of $95.16 \%, 93.93 \%$, and $95.45 \%$, respectively, showing better lipid peroxidation inhibitory activity than the reference antioxidants BHT, $\alpha$-tocopherol, and trolox. When the TACs of the reference antioxidants and the phenolic and flavonoid compounds were compared, the antioxidant activity observed, from highest to lowest, was as follows: ID$8>$ callistephin $>$ oenin $>$ BHA $>$ silychristin $>$ malvin $>$ pelargonin $>$ trolox $>$ BHT $>$ arachidonoyl dopamine $>2,4,6$ trihydroxybenzaldehyde $>3,4$-dihydroxy-5-methoxybenzoic acid $>\alpha$-tocopherol.

Elemental species such as $\mathrm{Fe}^{2+}$ accelerate ROS production in the body. Therefore, the Fe chelating activity of a substance may be related to its antioxidant activity. Among transition metals, Fe is known as the most important prooxidant that causes lipid peroxidation due to its high reactivity. Effective $\mathrm{Fe}^{2+}$ ion chelators prevent oxidative damage and oxidative stress-based diseases by binding $\mathrm{Fe}^{2+}$ ions, which can produce $\mathrm{OH}^{\bullet}$ radicals and are very reactive in Fenton-type reactions [37].

Similarly, this method is also performed using bipyridyl reactives. With this method, 3,4-dihydroxy-5-methoxybenzoic acid with $92 \%$ metal chelating capacity at $10 \mu \mathrm{g} / \mathrm{mL}$ concentration was more effective than the reference antioxidants and other phenolic and flavonoid compounds did, with the exception of EDTA (95.80\%). In addition, ID-8 and arachidonoyl dopamine with $88.06 \%$ and $73.86 \%$ metal chelating activity, respectively, demonstrated higher metal chelating activity than the other phenolic and flavonoid compounds and reference antioxidants did, with exception of EDTA and $\alpha$-tocopherol. Reference antioxidants and some phenolic and flavonoid compounds exhibited metal chelating activity to varying degrees (Table 1).

In the presence of chelating agents, the red color of the $\mathrm{Fe}^{2+}$-ferrozin complex, which exhibits maximum absorbance at $562 \mathrm{~nm}$ as a result of the reduction, decreases. Measuring the color decrease provides an estimate of the metal chelating activity of the chelating agent. Low absorbance indicates high metal chelating activity [38]. Kazazica et al. reported that flavonoids such as campherol exhibit $\mathrm{Cu}^{2+}$ and $\mathrm{Fe}^{2+}$ chelating activity via their functional groups [39]. Similarly, Fiorucci et al. showed that quercetin exhibits metal ion binding activity [40]. In another study, it was determined that L-carnitine chelates $\mathrm{Fe}^{2+}$ ions via its carbonyl and hydroxyl functional groups. Likewise, it has been proposed that curcumin chelates ferrous ions via its carbonyl and hydroxyl functional groups [41]. Similarly, L-adrenaline binds iron ions via its amine and 
TABLE 1: The comparison of lipid peroxidation inhibition percentages and ferrous ion $\left(\mathrm{Fe}^{2+}\right)$ chelating activities of reference antioxidants and some phenolic and flavonoid compounds $(10 \mu \mathrm{g} / \mathrm{mL}$ for chelating activity and $20 \mu \mathrm{g} / \mathrm{mL}$ for lipid peroxidation inhibition).

\begin{tabular}{|c|c|c|c|c|c|}
\hline \multirow[t]{2}{*}{ Antioxidant } & \multicolumn{2}{|c|}{$\begin{array}{l}\mathrm{Fe}^{2+} \text { ions chelating activity with } \\
\text { ferrozine reagent }\end{array}$} & \multicolumn{2}{|c|}{$\begin{array}{c}\mathrm{Fe}^{2+} \text { ions chelating activity with } \\
\text { bipyridyl reagent }\end{array}$} & \multirow{2}{*}{$\begin{array}{c}\text { Total antioxidant } \\
\text { activity } \\
\% \text { inhibition }\end{array}$} \\
\hline & $\mathrm{IC}_{50}(\mu \mathrm{g} / \mathrm{mL})$ & $\%$ activity & $\mathrm{IC}_{50}(\mu \mathrm{g} / \mathrm{mL})$ & $\%$ activity & \\
\hline BHA & 32.47 & 27.34 & 42.03 & 24.46 & 96.39 \\
\hline BHT & 30.07 & 34.89 & 31.98 & 28.86 & 63.63 \\
\hline$\alpha$-Tocopherol & 25.73 & 38.41 & 12.66 & 72.53 & 9.10 \\
\hline Trolox & 49.44 & 21.35 & 18.56 & 30.86 & 93.57 \\
\hline EDTA & - & - & 7.32 & 95.80 & - \\
\hline Malvin & 18.54 & 52.21 & 14.34 & 65.73 & 95.16 \\
\hline ID-8 & 18.33 & 54.16 & 8.80 & 88.06 & 97.98 \\
\hline Pelargonin & 25.72 & 39.58 & 14.30 & 51.46 & 93.93 \\
\hline Silychristin & 36.78 & 25.78 & 24.83 & 14.20 & 95.45 \\
\hline Callistephin & 34.51 & 22.73 & 20.80 & 33.06 & 97.58 \\
\hline Oenin & 28.95 & 22.00 & 26.47 & 16.40 & 96.75 \\
\hline Arachidonoyl Dopamine & 20.37 & 50.65 & 11.08 & 73.86 & 51.14 \\
\hline $\begin{array}{l}\text { 3,4-Dihydroxy-5-methoxybenzoic } \\
\text { acid }\end{array}$ & 26.93 & 36.32 & 52.37 & 92.00 & 17.23 \\
\hline 2,4,6-Trihydroxy benzaldehyde & 32.16 & 32.16 & 17.93 & 48.00 & 28.24 \\
\hline
\end{tabular}

The $\mathrm{IC}_{50}$ values were calculated by means of metal chelating and total antioxidant activity graphs from values measured at different concentrations $(10-30 \mu \mathrm{g} / \mathrm{mL})$ of reference antioxidants and the phenolic and flavonoid compounds.

hydroxyl groups [42]. We tested metal chelating activities of reference antioxidants and selected phenolic and flavonoid compounds at different concentrations $(10-30 \mu \mathrm{g} / \mathrm{mL})$ using ferrozine and bipyridyl reagents. In our study, ID-8, malvin, arachidonoyl dopamine, and pelargonin exhibited higher $\mathrm{Fe}^{2+}$ chelating activity than reference antioxidants and other phenolic and flavonoid compounds did at $10 \mu \mathrm{g} / \mathrm{mL}$ by chelating metal ions at levels of $54.16 \%, 52.21 \%, 50.65 \%$, and $39.58 \%$, respectively (Table 1 ). In addition, ID-8, arachidonoyl dopamine, malvin, and pelargonin, with $\mathrm{IC}_{50}$ values of $18.33,18.54,25.72$, and $20.37 \mu \mathrm{g} / \mathrm{mL}$, respectively, exhibited more effective $\mathrm{Fe}^{2+}$ ion chelating activity than reference antioxidants and the other phenolic and flavonoid compounds tested did (Table 1). Additionally, we hypothesized that $\mathrm{Fe}^{2+}$ chelating activities of the compounds in this study may be due to their - $\mathrm{OH}$ groups.

Determining metal chelating activity using the bipyridyl reagent was performed at different concentrations $(10-30 \mu \mathrm{g} / \mathrm{mL})$ of reference antioxidants and selected phenolic and flavonoid compounds. In the absorbance-quantity plot drawn according to the results obtained using bipyridyl reagent (Table 1), $\mathrm{IC}_{50}$ values of each substance were calculated from the curve corresponding to the $10 \mu \mathrm{g} / \mathrm{mL}$ concentration. ID-8 and arachidonoyl dopamine exhibited better metal chelating activity than other phenolic and flavonoid compounds tested and reference antioxidants did, except EDTA, with $\mathrm{IC}_{50}$ values of 8.80 and $11.08 \mu \mathrm{g} / \mathrm{mL}$, respectively (Table 1).

Free radical scavenging activity is very important because of the harmful effects of free radicals in biological systems and foods. Radical scavengers can react with free radicals directly to clear peroxide radicals, enhance the stability and quality of food products and drugs, and terminate peroxidation chain reactions [43]. This test is one of the standard tests in antioxidant activity studies and provides rapid results for the radical scavenging activity of specific compounds [44]. Free radicals scavenging assays based on the scavenging of $\mathrm{DPPH}^{\circ}$, $\mathrm{DMPD}^{\circ+}, \mathrm{ABTS}^{\bullet+}$, and $\mathrm{O}_{2}{ }^{--}$radicals are the most popular spectrophotometric methods used to determine the antioxidant capacities of foods, beverages, and plant extracts. In addition, these have advantages such as inexpensive reagents, less labor requirements, ease of use, high sensitivity, and ability to rapidly analyze antioxidant properties of numerous samples without complicated instruments [45]. When antioxidants are added to a medium containing radicals, $\mathrm{DPPH}^{\circ}$, $\mathrm{DMPD}^{\circ+}$, and $\mathrm{ABTS}^{\circ+}$ radicals are converted into their reduced forms, resulting in decolorization of the solution.

The DPPH radical scavenging assay is one of the oldest methods for determination of antioxidant activity [34]. The DPPH radical is an unstable organic nitrogen radical with a dark blue color. In this method, antioxidants reduce the stable DPPH radicals to yellow diphenyl-picrylhydrazine. This method is based on the fact that these radicals are converted to DPPH-H, the nonradical reduced form of the DPPH radicals, upon hydrogen donation by antioxidants in the alcohol solution [46]. The purple-colored, stable, free DPPH radical exhibits maximum absorbance at $517 \mathrm{~nm}$. When DPPH radicals contact a proton donor substrate, they are cleared and the absorbance decreases [47].

Resveratrol is one of the main phenolic compounds found in grapes. Gülçin showed that resveratrol is an effective DPPH radical scavenger [48]. The $\mathrm{DPPH}^{\circ}$ scavenging activity of the reference antioxidants and phenolic and flavonoid compounds at different concentrations 
TABLE 2: Free radical scavenging activities (\%) of reference antioxidants and selected phenolic and flavonoid compounds at $10 \mu \mathrm{g} / \mathrm{mL}$ concentration for ABTS and DMPD and at $20 \mu \mathrm{g} / \mathrm{mL}$ for $\mathrm{O}_{2}{ }^{--}$and DPPH${ }^{*}$.

\begin{tabular}{|c|c|c|c|c|c|c|c|c|}
\hline \multirow[b]{2}{*}{ Antioxidant } & \multicolumn{2}{|c|}{$\mathrm{DPPH}^{\circ}$} & \multicolumn{2}{|c|}{ DMPD $^{\bullet+}$} & \multicolumn{2}{|c|}{$\mathrm{ABTS}^{\bullet+}$} & \multicolumn{2}{|c|}{$\mathrm{O}_{2}^{\cdot-}$} \\
\hline & $\begin{array}{c}\mathrm{IC}_{50} \\
(\mu \mathrm{g} / \mathrm{mL})\end{array}$ & $\%$ activity & $\begin{array}{c}\mathrm{IC}_{50} \\
(\mu \mathrm{g} / \mathrm{mL})\end{array}$ & $\%$ activity & $\begin{array}{c}\mathrm{IC}_{50} \\
(\mu \mathrm{g} / \mathrm{mL})\end{array}$ & $\%$ activity & $\begin{array}{c}\mathrm{IC}_{50} \\
(\mu \mathrm{g} / \mathrm{mL})\end{array}$ & $\%$ activity \\
\hline BHA & 8.09 & 98.64 & 15.34 & 15.34 & 3.60 & 99.80 & 23.37 & 41.06 \\
\hline BHT & 11.89 & 96.28 & 15.26 & 15.26 & 6.04 & 99.80 & 15.02 & 64.60 \\
\hline$\alpha$-Tocopherol & 17.25 & 93.85 & 15.14 & 64.14 & 8.47 & 70.63 & 23.21 & 42.00 \\
\hline Trolox & 14.13 & 95.21 & 13.90 & 64.57 & 7.39 & 83.72 & 23.21 & 44.00 \\
\hline Malvin & 21.36 & 92.21 & 16.47 & 59.85 & 7.20 & 81.72 & 30.97 & 33.06 \\
\hline ID-8 & 536.41 & 93.85 & 17.56 & 60.28 & 6.80 & 82.63 & 34.73 & 30.66 \\
\hline Pelargonin & 67.73 & 91.50 & 15.86 & 65.85 & 6.71 & 93.54 & 14.13 & 63.40 \\
\hline Silychristin & 86.16 & 91.07 & 17.62 & 61.71 & 6.71 & 89.18 & 18.19 & 51.86 \\
\hline Callistephin & 20.64 & 95.57 & 12.80 & 72.71 & 5.54 & 99.72 & 19.70 & 49.60 \\
\hline Oenin & 16.72 & 95.35 & 15.46 & 65.85 & 6.60 & 99.72 & 16.70 & 56.40 \\
\hline Arachidonoyl dopamine & 84.10 & 98.50 & 18.02 & 59.71 & 12.54 & 42.00 & 23.95 & 39.40 \\
\hline $\begin{array}{l}\text { 3,4-Dihydroxy-5-methoxybenzoic } \\
\text { acid }\end{array}$ & 10.69 & 98.64 & 17.80 & 64.42 & 6.05 & 99.80 & 11.47 & 73.40 \\
\hline 2,4,6-Trihydroxy benzaldehyde & 28.86 & 96.78 & 17.93 & 70.00 & 5.28 & 99.72 & 16.54 & 56.80 \\
\hline
\end{tabular}

The $\mathrm{IC}_{50}$ values were calculated by means of radical scavenging activity graphs from the values measured at different concentrations $(10-30 \mu \mathrm{g} / \mathrm{mL})$ of reference antioxidants and some phenolic and flavonoid compounds.

$(10-30 \mu \mathrm{g} / \mathrm{mL})$ was measured at $517 \mathrm{~nm}$. As the concentration of the substance increased the amount of free radicals in the mixture decreased proportionally for almost all phenolic and flavonoid compounds. In our study, 3,4-dihydroxy-5methoxybenzoic acid, with an $\mathrm{IC}_{50}$ value of $10.69 \mu \mathrm{g} / \mathrm{mL}$ showed more DPPH radical scavenging activity than the reference antioxidants BHT, $\alpha$-tocopherol, and trolox. ID8 with an $\mathrm{IC}_{50}$ value of $536.41 \mu \mathrm{g} / \mathrm{mL}$ exhibited the lowest DPPH radical scavenging activity of the compounds examined. However, all the test materials showed dose-dependent DPPH radical scavenging activity (Table 2 ).

Superoxide anion radicals are biologically highly toxic and are produced by the immune system to kill microorganisms. In vivo, superoxide can be produced as a result of an electron being transferred to oxygen because of various metabolic processes or activation of oxygen by a radical [49]. Although superoxide radicals have relatively limited chemical reactivity and are a weak oxidant, they can produce very dangerous reactive components such as singlet oxygen and hydroxyl radicals that cause lipid peroxidation [50]. It has also been observed that superoxide radical directly initiates lipid peroxidation [51]. When the riboflavin used in this method is photochemically activated, it reacts with NBT to produce $\mathrm{NBTH}^{\circ}$. The NBTH radical leads to formazan formation. In the presence of oxygen, radical species are controlled by a semiequilibrium reaction. With the presence of antioxidants that donate electrons to NBT, the degradation of the typical purple color of formazan can be monitored spectrophotometrically at $560 \mathrm{~nm}$. Antioxidants have the ability to inhibit the conversion of NBT. Decreased absorbance at $560 \mathrm{~nm}$ in the presence of antioxidants indicates that the superoxide anion radicals are scavenged [9]. The results obtained with this method showed that 3,4-dihydroxy-5-methoxybenzoic acid and pelargonin, with $\mathrm{IC}_{50}$ values of 11.47 and $14.13 \mu \mathrm{g} / \mathrm{mL}$, respectively, possessed better $\mathrm{O}_{2}{ }^{--}$anion radical scavenging activity than the other phenolic and flavonoid compounds and the reference antioxidants BHA, BHT, $\alpha$-tocopherol, and trolox did (Table 2). Additionally, oenin, callistephin, silychristin, and 2,4,6-trihydroxybenzaldehyde showed better $\mathrm{O}_{2}{ }^{--}$anion radical scavenging properties than the reference antioxidants BHA, $\alpha$-tocopherol, and trolox did, and all other substances exhibited dose-dependent $\mathrm{O}_{2}{ }^{\cdot-}$ scavenging activity.

ABTS is oxidized by oxidants into the intensely colored $\mathrm{ABTS}^{\bullet+}$ cation. In this method, antioxidant capacity was measured by the decolorization ability of some phenolic and flavonoid compounds from reaction of ABTS radicals and the antioxidants added to the medium. The ABTS assay can be applied to both lipophilic and hydrophilic compounds [52]. This method is based on the principle that the ABTS radical cation shows maximum absorbance at $734 \mathrm{~nm}$. Reaction with the ABTS radical occurs in a time as short as 0.25 to $0.5 \mathrm{~min}$. The radical scavenging performance of free radical scavengers can be determined by monitoring the decrease in absorbance at $734 \mathrm{~nm}$ [47].

The $\mathrm{ABTS}^{\bullet+}$ radical scavenging activity was determined for concentrations of 5,10 , and $20 \mu \mathrm{g} / \mathrm{mL}$ of reference antioxidants and the phenolic and flavonoid compounds. According to the results, 2,4,6-trihydroxybenzaldehyde, oenin, callistephin, and ID- 8 at $5 \mu \mathrm{g} / \mathrm{mL}$ concentration exhibited higher $\mathrm{ABTS}^{\circ+}$ radical scavenging activities than the other phenolic and flavonoid compounds and the reference antioxidants (BHT, trolox, and $\alpha$-tocopherol) (Table 2 ). In addition, callistephin and 2,4,6-trihydroxybenzaldehyde with $\mathrm{IC}_{50}$ values of 5.28 and $5.54 \mu \mathrm{g} / \mathrm{mL}$, respectively, showed higher $\mathrm{ABTS}^{\circ+}$ radical scavenging activity than the phenolic and 
flavonoid compounds and the reference antioxidants BHT, $\alpha$-tocopherol, and trolox did. In addition, 3,4-dihydroxy-5methoxybenzoic acid, oenin, silychristin, pelargonin, ID-8, and malvin exhibited $\mathrm{IC}_{50}$ values of $6.05,6.60,6.71,6.71$, 6.80, and $7.20(\mu \mathrm{g} / \mathrm{mL})$, respectively. They showed better ABTS radical scavenging activity than the examined phenolic and flavonoid compounds and the reference antioxidants $\alpha$ tocopherol and trolox. In addition, all compounds examined showed dose-dependent $\mathrm{ABTS}^{\bullet+}$ radical scavenging activity.

Another method that is similar to the ABTS radical scavenging assay is the DMPD radical scavenging method. Tohma and Gulçin proposed this new version of the ABTS test [35]. In this method, the ABTS radical is substituted with the stable $\mathrm{DMPD}^{\bullet+}$ radical cation formed from N,Ndimethylphenylenediamine $[28,53]$. They reported that $\mathrm{DMPD}^{\circ+}$ radical scavenging activity was more efficient and the test was less expensive than the $\mathrm{ABTS}^{\bullet+}$ radical scavenging method. DMPD is converted to colored, stable DMPD ${ }^{\circ+}$ radical cation in the presence of oxidants and an acidic medium. The visible spectrum of $\mathrm{DMPD}^{\circ+}$ radical exhibits maximum absorbance at $505 \mathrm{~nm}$. However, DMPD cannot be used with hydrophobic antioxidants because it dissolves in water only [28]. When hydrophobic antioxidants are used, the sensitivity and reproducibility of the assay drop dramatically [54]. Antioxidant compounds decolorize the solution by donating a hydrogen atom to DMPD radicals [28, 41]. DMPD ${ }^{\bullet}$ radical scavenging activity was assayed for different concentrations $(10-30 \mu \mathrm{g} / \mathrm{mL})$ of reference antioxidants and some phenolic and flavonoid compounds. The results showed that the DMPD ${ }^{\bullet}$ scavenging activities of the reference antioxidants and some phenolic and flavonoid compounds were very similar (Table 2). At $30 \mu \mathrm{g} / \mathrm{mL}$ concentration, 2,4,6trihydroxy-benzaldehyde exhibited better DMPD scavenging activity than the other phenolic and flavonoid compounds and the reference antioxidants BHA, BHT, and $\alpha$-tocopherol. In addition, callistephin and 2,4,6-trihydroxybenzaldehyde with $\mathrm{IC}_{50}$ values of 13.27 and $12.80 \mu \mathrm{g} / \mathrm{mL}$, respectively, exhibited better $\mathrm{DMPD}^{\circ+}$ radicals removal activity than the other phenolic and flavonoid compounds and the reference antioxidants BHA, BHT, $\alpha$-tocopherol, and trolox did. In addition, all the compounds tested here exhibited dosedependent $\mathrm{DMPD}^{\bullet+}$ radical scavenging activity.

Antioxidants, which can effectively reduce prooxidants, can also effectively reduce $\mathrm{Fe}^{3+}$ to $\mathrm{Fe}^{2+}$ [55]. Therefore, the reducing power of a compound provides important information about its antioxidant activity. Reduction ability is one of the most important antioxidant properties of a compound [56]. The three methods used to determine reduction activity in this study measured the reduction of $\mathrm{Cu}^{2+}, \mathrm{Fe}^{3+}$ (using ferrozine reagent), and $\mathrm{Fe}^{3+}$ (using the FRAP reagent).

The $\mathrm{Fe}^{3+}-\mathrm{Fe}^{2}$ reduction activity of the reference antioxidants and some phenolic and flavonoid compounds using tripyridyltriazine (TPTZ) was determined by measuring the formation of the blue $\mathrm{Fe}^{2+}$-TPTZ complex at a wavelength of $593 \mathrm{~nm}$ (FRAP assay).

$\mathrm{Fe}^{3+}-\mathrm{Fe}^{2}$ reduction activities of almost all of the reference antioxidants and phenolic and flavonoid compounds increased proportionally with their concentration (Table 3).
TABLE 3: $\mathrm{Fe}^{3+}$ and $\mathrm{Cu}^{2+}$ reducing activities of reference antioxidants and selected phenolic and flavonoid compounds at $30 \mu \mathrm{g} / \mathrm{mL}$ concentration.

\begin{tabular}{lcc}
\hline Antioxidant & $\begin{array}{c}\text { FRAP assay } \\
(593 \mathrm{~nm})\end{array}$ & $\begin{array}{c}\text { CUPRAC assay } \\
(450 \mathrm{~nm})\end{array}$ \\
\hline BHA & 2.344 & 0.489 \\
BHT & 2.430 & 0.476 \\
$\alpha$-Tocopherol & 2.259 & 0.403 \\
Trolox & 2.086 & 0.330 \\
Malvin & 2.189 & 0.431 \\
ID-8 & 0.615 & 0.145 \\
Pelargonin & 2.064 & 0.385 \\
Silychristin & 1.181 & 0.259 \\
Callistephin & 2.328 & 0.456 \\
Oenin & 2.351 & 0.464 \\
Arachidonoyl Dopamine & 1.392 & 0.308 \\
3,4-Dihydroxy-5- & & \\
methoxybenzoic & 2.458 & 0.474 \\
acid & & \\
2,4,6-Trihydroxybenzaldehyde & 1.839 & 0.466 \\
\hline
\end{tabular}

3,4-dihydroxy-5-methoxybenzoic acid exhibited better $\mathrm{Fe}^{3+}$ $\mathrm{Fe}^{2}$ reduction capacity than the reference antioxidants and the other phenolic and flavonoid compounds examined. In addition, callistephin and oenin showed more effective $\mathrm{Fe}^{3+}$ $\mathrm{Fe}^{2}$ reduction activity than the reference antioxidants trolox and $\alpha$-tocopherol did. When $\mathrm{Fe}^{3+}-\mathrm{Fe}^{2}$ reduction activities of the reference antioxidants and phenolic and flavonoid compounds were compared at $30 \mu \mathrm{g} / \mathrm{mL}$ using the FRAP reagent, the antioxidant activities observed, from highest to lowest were as follows: 3,4-dihydroxy-5-methoxybenzoic acid $>$ BHT $>$ oenin $>$ BHA $>$ callistephin $>$ trolox $>$ malvin $>$ $\alpha$-tocopherol $>$ pelargonin $>2,4,6$-trihydroxybenzaldehyde $>$ arachidonoyl dopamine $>$ silychristin $>$ ID-8.

The CUPRAC assay measuring the reduction of $\mathrm{Cu}^{2+}$ to $\mathrm{Cu}^{+}$was described by Gülçin et al. [57]. This method is based on the reduction of $\mathrm{Cu}^{2+}$ to $\mathrm{Cu}^{+}$at $\mathrm{pH} 7$ in aqueous ethanol with the combined effect of antioxidants in the presence of neocuproine (2,9-dimethyl-1,10-phenanthrene). The $\mathrm{Cu}^{+}$complex formed by the phenols shows maximum absorbance at $450 \mathrm{~nm}$ [58]. This method is suitable for a wide variety of antioxidants, both hydrophilic and hydrophobic substances, because it is low-cost, fast, stable, and selective. Furthermore, the chromogenic CUPRAC redox reaction occurs at physiological $\mathrm{pH}$ and is commonly used to compare nonprotein thiol-type antioxidants, such as glutathione, as opposed to the FRAP method, which does not respond to antioxidants containing SH groups [59].

The results obtained with this method showed dosedependent $\mathrm{Cu}^{2+}$ reduction activity for all phenolic and flavonoid compounds. In addition, $30 \mu \mathrm{g} / \mathrm{mL}, 2,4,6$-trihydroxybenzaldehyde, 3,4-dihydroxy-5-methoxybenzoic acid, malvin, oenin, and callistephin exhibited absorbance values of $0.431,0.464,0.456,0.466$, and 0.474 , respectively, in the $\mathrm{Cu}^{2+}-\mathrm{Cu}^{+}$reduction assay, which were higher than the values 
obtained for other phenolic and flavonoid compounds and trolox and $\alpha$-tocopherol, the reference antioxidants (Table 3 ).

\section{Conclusion}

Our data demonstrate the difference in antioxidant activities of the reference antioxidants and selected phenolic and flavonoid compounds in different assays. This may be due to the fact that the different antioxidant capacity determining methods have different specificities for different solvents, reagents, $\mathrm{pH}$ conditions, or hydrophilic and hydrophobic substances. Furthermore, molecular size and the number and type of functional groups of the phenolic and flavonoid compounds may be important. Oenin, malvin, arachidonoyl dopamine, callistephin, silychristin, and 3,4-dihydroxy-5methoxybenzoic acid exhibited better antioxidant activities than the reference antioxidants did. Therefore, these compounds may have the potential to protect and maintain food and medicines and reduce oxidative stress or increase antioxidant capacity in vivo: this conclusion should be further validated by future studies.

\section{Conflicts of Interest}

The authors declare that there are no conflicts of interest regarding the publication of this article.

\section{Authors' Contributions}

Zübeyir Huyut and Şükrü Beydemir researched literature and conceived the study. Zübeyir Huyut was involved in protocol development, experimental studies, and data analysis. Zübeyir Huyut, Şükrü Beydemir, and İlhami Gülçin wrote the first draft of the manuscript. All authors reviewed and edited the manuscript and approved the final version of the manuscript.

\section{Acknowledgments}

This study was performed with opportunities from Departments of Biochemistry, Faculty of Science, Atatürk University, and Faculty of Medicine, Yuzuncu Yll University.

\section{References}

[1] K. Aksu, B. Özgeriş, P. Taslimi, A. Naderi, İ. Gülçin, and S. Göksu, "Antioxidant Activity, Acetylcholinesterase, and Carbonic Anhydrase Inhibitory Properties of Novel Ureas Derived from Phenethylamines," Archiv der Pharmazie, vol. 349, no. 12, pp. 944-954, 2016.

[2] I. Gülçin, V. Mshvildadze, A. Gepdiremen, and R. Elias, "Screening of antiradical and antioxidant activity of monodesmosides and crude extract from Leontice smirnowii tuber," Phytomedicine, vol. 13, no. 5, pp. 343-351, 2006.

[3] M. M. Ibrahim, G. A. M. Mersal, A.-M. M. Ramadan, S. Y. Shaban, M. A. Mohamed, and S. Al-Juaid, "Synthesis, characterization and antioxidant/cytotoxic activity of oxovanadium(IV) complexes of methyliminodiacetic acid and ethylenediaminetetracetic acid," Journal of Molecular Structure, vol. 1137, pp. 742755, 2017.
[4] C. A. Prauchner, "Oxidative stress in sepsis: Pathophysiological implications justifying antioxidant co-therapy," Burns, vol. 43, no. 3, pp. 471-485, 2017.

[5] J. Li, O. Wuliji, W. Li, Z.-G. Jiang, and H. A. Ghanbari, "Oxidative stress and neurodegenerative disorders," International Journal of Molecular Sciences, vol. 14, no. 12, pp. 2443824475, 2013.

[6] J.-M. Lü, P. H. Lin, Q. Yao, and C. Chen, "Chemical and molecular mechanisms of antioxidants: experimental approaches and model systems," Journal of Cellular and Molecular Medicine, vol. 14, no. 4, pp. 840-860, 2010.

[7] S. Catarzi, C. Romagnoli, G. Marcucci, F. Favilli, T. Iantomasi, and M. T. Vincenzini, "Redox regulation of ERK1/2 activation induced by sphingosine 1-phosphate in fibroblasts: involvement of NADPH oxidase and platelet-derived growth factor receptor," Biochimica et Biophysica Acta, vol. 1810, no. 4, pp. 446-456, 2011.

[8] A. Rahal, A. Kumar, and V. Singh, "Oxidative stress, prooxidants, and antioxidants: the interplay," BioMed Research International, vol. 2014, Article ID 761264, 19 pages, 2014.

[9] L. A. Pham-Huy, H. He, and C. Pham-Huy, "Free radicals, antioxidants in disease and health," International Journal of Biomedical Science, vol. 4, pp. 89-96, 2008.

[10] E. Bursal and I. Gülçin, "Polyphenol contents and in vitro antioxidant activities of lyophilised aqueous extract of kiwifruit (Actinidia deliciosa)," Food Research International, vol. 44, no. 5, pp. 1482-1489, 2011.

[11] Y. Çetinkaya, H. Göçer, A. Menzek, and I. Gülçin, "Synthesis and antioxidant properties of (3,4-dihydroxyphenyl)(2,3,4trihydroxyphenyl)methanone and its derivatives," Archiv der Pharmazie, vol. 345, no. 4, pp. 323-334, 2012.

[12] D. Giordano, M. Locatelli, F. Travaglia et al., "Bioactive compound and antioxidant activity distribution in roller-milled and pearled fractions of conventional and pigmented wheat varieties," Food Chemistry, vol. 233, pp. 483-491, 2017.

[13] S. Gonçalves, E. Moreira, C. Grosso, P. B. Andrade, P. Valentão, and A. Romano, "Phenolic profile, antioxidant activity and enzyme inhibitory activities of extracts from aromatic plants used in Mediterranean diet," Journal of Food Science and Technology, vol. 54, no. 1, pp. 219-227, 2017.

[14] P. A. Hannan, J. A. Khan, I. Ullah, and S. Ullah, "Synergistic combinatorial antihyperlipidemic study of selected natural antioxidants; Modulatory effects on lipid profile and endogenous antioxidants," Lipids in Health and Disease, vol. 15, no. 1, article no. 151, 2016.

[15] T. A. Comunian, R. Ravanfar, I. A. de Castro, R. Dando, C. S. Favaro-Trindade, and A. Abbaspourrad, "Improving oxidative stability of echium oil emulsions fabricated by Microfluidics: effect of ionic gelation and phenolic compounds," Food Chemistry, vol. 233, pp. 125-134, 2017.

[16] F. Shahidi and P. Ambigaipalan, "Phenolics and polyphenolics in foods, beverages and spices: Antioxidant activity and health effects - A review," Journal of Functional Foods, vol. 18, pp. 820897, 2015.

[17] D. C. Vodnar, L. F. Călinoiu, F. V. Dulf, B. E. Ştefănescu, G. Crişan, and C. Socaciu, "Identification of the bioactive compounds and antioxidant, antimutagenic and antimicrobial activities of thermally processed agro-industrial waste," Food Chemistry, vol. 231, pp. 131-140, 2017.

[18] P. G. Pietta, "Flavonoids as antioxidants," Journal of Natural Products, vol. 63, no. 7, pp. 1035-1042, 2000.

[19] J. Anissi, M. El Hassouni, A. Ouardaoui, and K. Sendide, "A comparative study of the antioxidant scavenging activity of 
green tea, black tea and coffee extracts: A kinetic approach," Food Chemistry, vol. 150, pp. 438-447, 2014.

[20] H. N. Thatoi, J. K. Patra, and S. K. Das, "Free radical scavenging and antioxidant potential of mangrove plants: A review," Acta Physiologiae Plantarum, vol. 36, no. 3, pp. 561-579, 2014.

[21] I. Gülçin, "Antioxidant activity of food constituents: an overview," Archives of Toxicology, vol. 86, no. 3, pp. 345-391, 2012.

[22] H. Mitsuda, K. Yuasumoto, and K. Iwami, "Antioxidation action of indole compounds during the autoxidation of linoleic acid," Eiyo to Shokuryo, vol. 19, pp. 210-214, 1996.

[23] M. Oyaizu, "Studies on product of browning reaction prepared from glucoseamine," Japanese Journal of Nutrition and Dieteteics, vol. 44, pp. 307-315, 1986.

[24] R. Apak, K. Güçlü, M. Özyürek, S. Esin Karademir, and E. Erçağ, "The cupric ion reducing antioxidant capacity and polyphenolic content of some herbal teas," International Journal of Food Sciences and Nutrition, vol. 57, no. 5-6, pp. 292-304, 2006.

[25] J. Zhishen, T. Mengcheng, and W. Jianming, "The determination of flavonoid contents in mulberry and their scavenging effects on superoxide radicals," Food Chemistry, vol. 64, no. 4, pp. 555$559,1999$.

[26] M. S. Blois, "Antioxidant determinations by the use of a stable free radical," Nature, vol. 181, no. 4617, pp. 1199-1200, 1958.

[27] R. Re, N. Pellegrini, A. Proteggente, A. Pannala, M. Yang, and C. Rice-Evans, "Antioxidant activity applying an improved ABTS radical cation decolorization assay," Free Radical Biology \& Medicine, vol. 26, no. 9-10, pp. 1231-1237, 1999.

[28] V. Fogliano, V. Verde, G. Randazzo, and A. Ritieni, "Method for measuring antioxidant activity and its application to monitoring the antioxidant capacity of wines," Journal of Agricultural and Food Chemistry, vol. 47, no. 3, pp. 1035-1040, 1999.

[29] T. C. P. Dinis, V. M. C. Madeira, and L. M. Almeida, "Action of phenolic derivatives (acetaminophen, salicylate, and 5aminosalicylate) as inhibitors of membrane lipid peroxidation and as peroxyl radical scavengers," Archives of Biochemistry and Biophysics, vol. 315, no. 1, pp. 161-169, 1994.

[30] A. T. Diplock, "Erratum: Will the 'good fairies' please prove to us that vitamin E lessens human degenerative disease? (Free Radical Research 26 (565-583))," Free Radical Research, vol. 27, no. 5, pp. 511-532, 1997.

[31] R. L. Prior, X. Wu, and K. Schaich, "Standardized methods for the determination of antioxidant capacity and phenolics in foods and dietary supplements," Journal of Agricultural and Food Chemistry, vol. 53, no. 10, pp. 4290-4302, 2005.

[32] M. Qasim, Z. Abideen, M. Y. Adnan et al., "Antioxidant properties, phenolic composition, bioactive compounds and nutritive value of medicinal halophytes commonly used as herbal teas," South African Journal of Botany, vol. 110, pp. 240-250, 2017.

[33] I. Gülçin, M. Elmastaş, and H. Y. Aboul-Enein, "Antioxidant activity of clove oil - A powerful antioxidant source," Arabian Journal of Chemistry, vol. 5, no. 4, pp. 489-499, 2012.

[34] V. Roginsky and E. A. Lissi, "Review of methods to determine chain-breaking antioxidant activity in food," Food Chemistry, vol. 92, no. 2, pp. 235-254, 2005.

[35] H. S. Tohma and I. Gulçin, "Antioxidant and radical scavenging activity of aerial parts and roots of Turkish liquorice (Glycyrrhiza glabra L.)," International Journal of Food Properties, vol. 13, no. 4, pp. 657-671, 2010.

[36] I. Gülçin, Ö. I. Küfrevioğlu, M. Oktay, and M. E. Büyükokuroğlu, "Antioxidant, antimicrobial, antiulcer and analgesic activities of nettle (Urtica dioica L.)," Journal of Ethnopharmacology, vol. 90, no. 2-3, pp. 205-215, 2004.
[37] S. Hippeli and E. F. Elstner, "Transition metal ion-catalysed oxygen activation during pathogenic processes," FEBS Letters, vol. 443, no. 1, pp. 1-7, 1999.

[38] I. Gülçin, M. Oktay, E. Kireçci, and Ö. I. Küfrevıoğlu, "Screening of antioxidant and antimicrobial activities of anise (Pimpinella anisum L.) seed extracts," Food Chemistry, vol. 83, no. 3, pp. 371382, 2003.

[39] S. P. Kazazić, V. Butković, D. Srzić, and L. Klasinc, "Gas-phase ligation of $\mathrm{Fe}^{2+}$ and $\mathrm{Cu}^{+}$ions with some flavonoids," Journal of Agricultural and Food Chemistry, vol. 54, pp. 8391-8396, 2006.

[40] S. Fiorucci, J. Golebiowski, D. Cabrol-Bass, and S. Antonczak, "DFT study of quercetin activated forms involved in antiradical, antioxidant, and prooxidant biological processes," Journal of Agricultural and Food Chemistry, vol. 55, no. 3, pp. 903-911, 2007.

[41] T. Ak and I. Gülçin, "Antioxidant and radical scavenging properties of curcumin," Chemico-Biological Interactions, vol. 174, no. 1, pp. 27-37, 2008.

[42] I. Gülçin, "Antioxidant activity of 1-adrenaline: A structureactivity insight," Chemico-Biological Interactions, vol. 179, no. 23, pp. 71-80, 2009.

[43] E. Köksal, I. Gülçin, S. Beyza, Ö. Sarikaya, and E. Bursal, "In vitro antioxidant activity of silymarin," Journal of Enzyme Inhibition and Medicinal Chemistry, vol. 24, no. 2, pp. 395-405, 2009.

[44] B. Ozcelik, J. H. Lee, and D. B. Min, "Effects of light, oxygen, and $\mathrm{pH}$ on the absorbance of 2,2-diphenyl-1-picrylhydrazyl," Journal of Food Science, vol. 68, no. 2, pp. 487-490, 2003.

[45] I. Gülçin, D. Berashvili, and A. Gepdiremen, "Antiradical and antioxidant activity of total anthocyanins from Perilla pankinensis decne," Journal of Ethnopharmacology, vol. 101, no. 1-3, pp. 287-293, 2005.

[46] M. Elmastas, İ. Türkekul, L. Öztürk, I. Gülçin, Ö. Isildak, and H. Y. Aboul-Enein, "The antioxidant activity of two wild edible mushrooms (Morchella vulgaris and Morchella esculanta)," in Combinatorial Chemistry \& High Throughput Screening, vol. 9, pp. 443-448, 2006.

[47] I. Gülçin, R. Elias, A. Gepdiremen, K. Taoubi, and E. Köksal, "Antioxidant secoiridoids from fringe tree (Chionanthus virginicus L.)," Wood Science and Technology, vol. 43, no. 3-4, pp. 195-212, 2009.

[48] I. Gülçin, "Antioxidant properties of resveratrol: a structureactivity insight," Innovative Food Science and Emerging Technologies, vol. 11, no. 1, pp. 210-218, 2010.

[49] B. Halliwell, "Phagocyte-derived reactive species: salvation or suicide?" Trends in Biochemical Sciences, vol. 31, no. 9, pp. 509$515,2006$.

[50] B. Halliwell and S. Chirico, "Lipid peroxidation: its mechanism, measurement, and significance," The American Journal of Clinical Nutrition, vol. 57, pp. 715-725, 1993.

[51] A. P. Wickens, "Ageing and the free radical theory," Respiration Physiology, vol. 128, no. 3, pp. 379-391, 2001.

[52] L. M. Magalhães, M. A. Segundo, S. Reis, and J. L. F. C. Lima, "Methodological aspects about in vitro evaluation of antioxidant properties," Analytica Chimica Acta, vol. 613, no. 1, pp. 1-19, 2008.

[53] K. Schlesier, M. Harwat, V. Böhm, and R. Bitsch, "Assessment of antioxidant activity by using different in vitro methods," Free Radical Research, vol. 36, no. 2, pp. 177-187, 2002.

[54] C. Sánchez-Moreno, "Review: methods used to evaluate the free radical scavenging activity in foods and biological systems," 
Food Science and Technology International, vol. 8, no. 3, pp. 121137, 2002.

[55] N. Öztaşkin, Y. Çetinkaya, P. Taslimi, S. Göksu, and I. Gülçin, "Antioxidant and acetylcholinesterase inhibition properties of novel bromophenol derivatives," Bioorganic Chemistry, vol. 60, pp. 49-57, 2015.

[56] S. Meir, J. Kanner, B. Akiri, and S. Philosoph-Hadas, "Determination and involvement of aqueous reducing compounds in oxidative defense systems of various senescing leaves," Journal of Agricultural and Food Chemistry, vol. 43, no. 7, pp. 1813-1819, 1995.

[57] I. Gülçin, R. Elias, A. Gepdiremen, A. Chea, and F. Topal, "Antioxidant activity of bisbenzylisoquinoline alkaloids from Stephania rotunda: Cepharanthine and fangchinoline," Journal of Enzyme Inhibition and Medicinal Chemistry, vol. 25, no. 1, pp. 44-53, 2010.

[58] G. Lee, M. V. Rossi, N. Coichev, and H. D. Moya, “The reduction of $\mathrm{Cu}(\mathrm{II}) /$ neocuproine complexes by some polyphenols: Total polyphenols determination in wine samples," Food Chemistry, vol. 126, no. 2, pp. 679-686, 2011.

[59] R. Apak, K. Güçlü, M. Özyürek, and S. E. Çelik, "Mechanism of antioxidant capacity assays and the CUPRAC (cupric ion reducing antioxidant capacity) assay," Microchimica Acta, vol. 160, no. 4, pp. 413-419, 2008. 

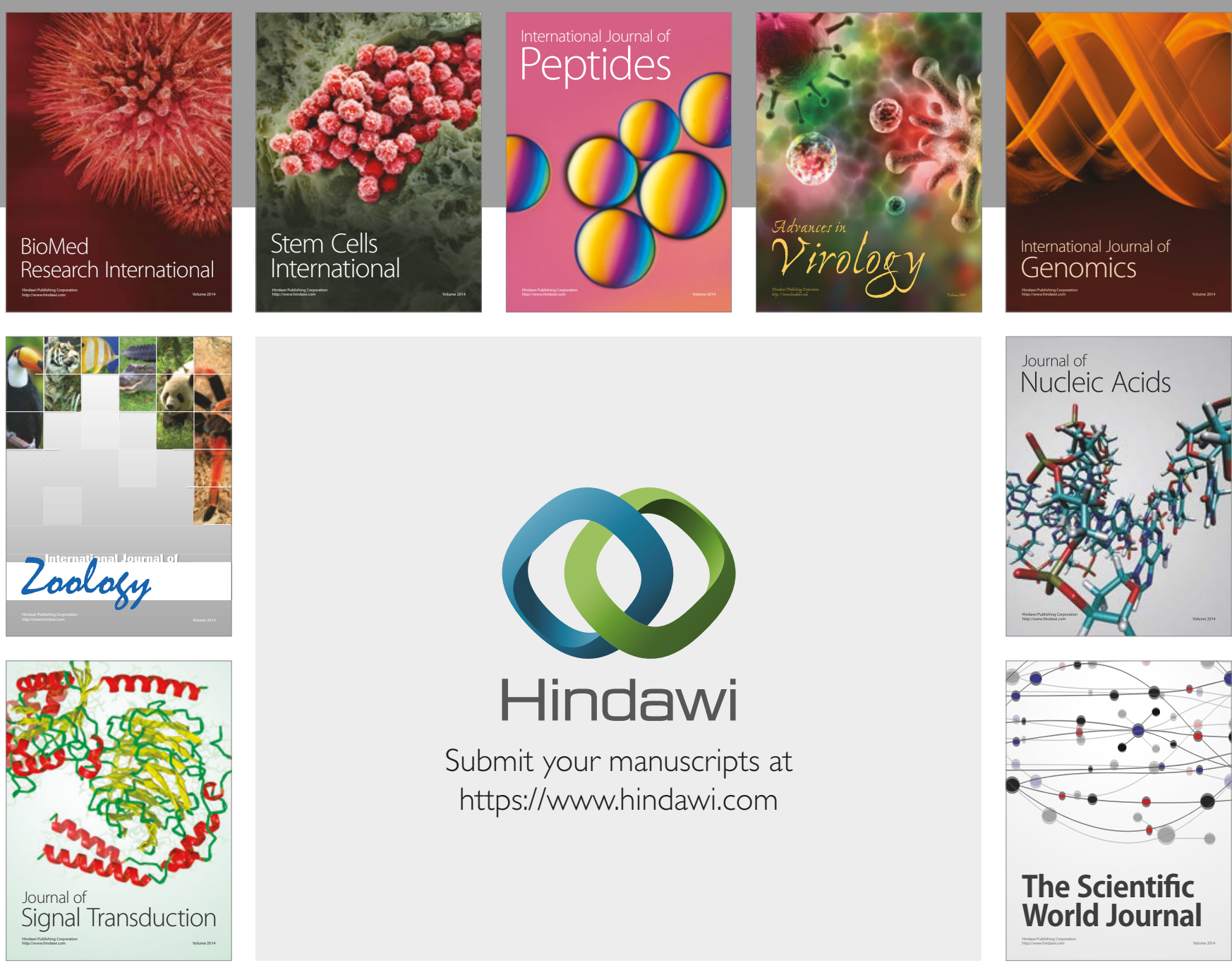

Submit your manuscripts at

https://www.hindawi.com
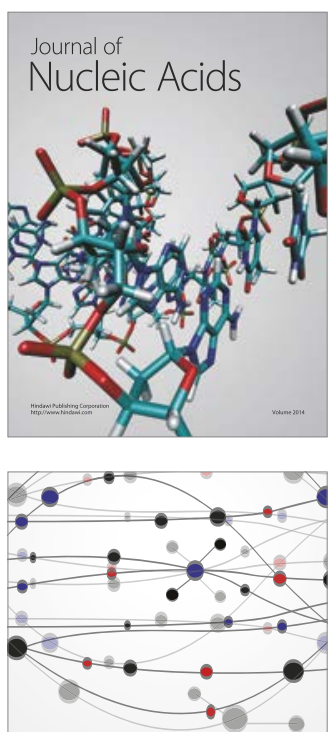

The Scientific World Journal

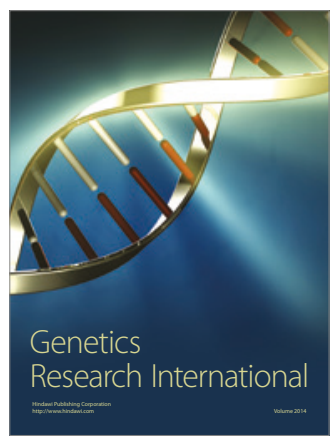

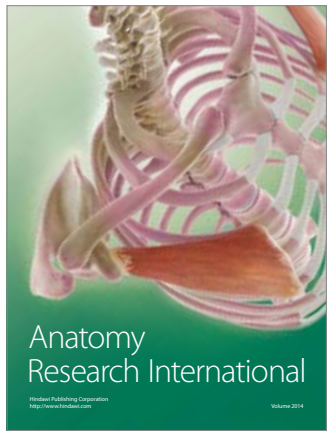

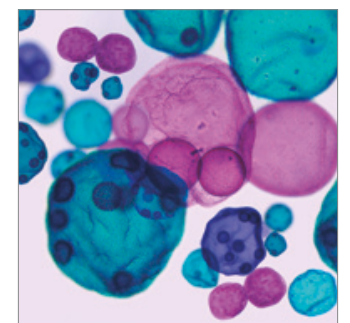

International Journal of Microbiology
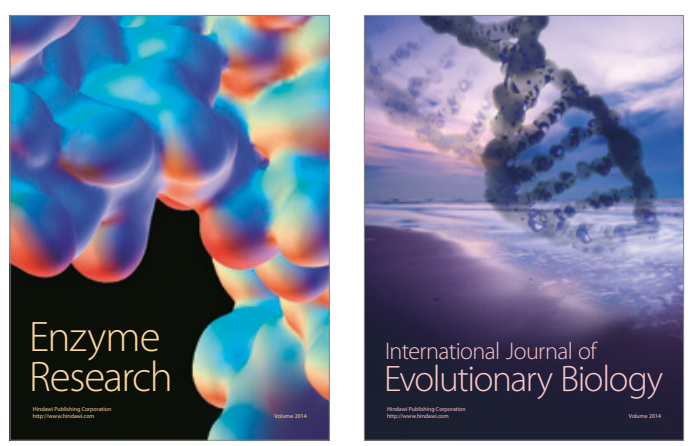
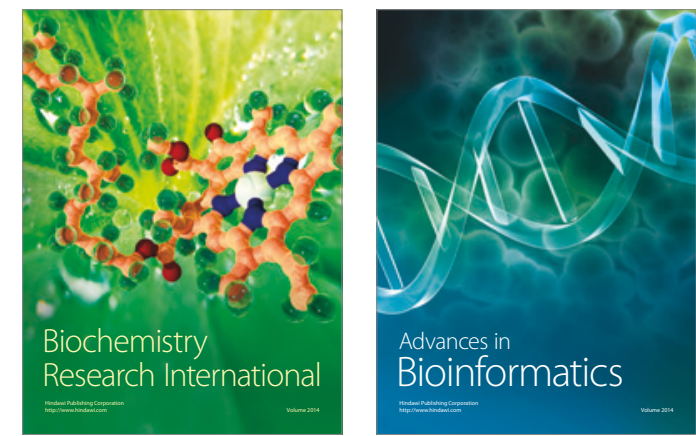

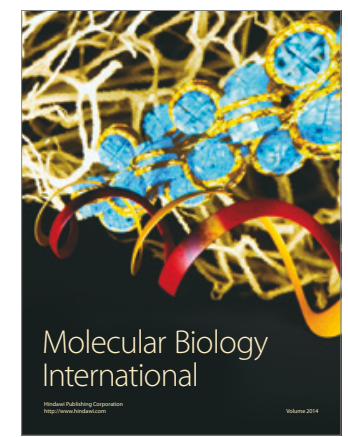

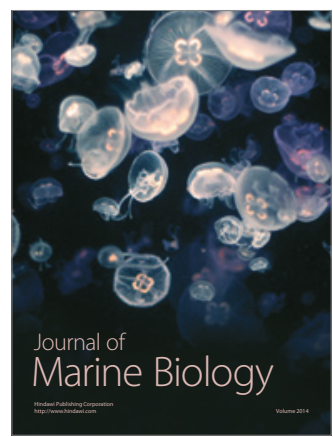

